\title{
EFFICIENCY ANALYSIS OF SUPPLIER PERFORMANCE MEASUREMENT SYSTEM
}

\author{
Csanád SIPOS \\ Department of Engineering Management, Faculty of Engineering, University of Debrecen \\ Ótemető u 2-4., H-4029 Debrecen, Hungary, e-mail: csanad.sipos@gmail.com
}

Received 30 December 2018; accepted 25 April 2019

\begin{abstract}
This study empirically investigates the effects of the special, face to face supplier performance measurement system. Using supplier performance measurement system the supplier will have the possibility to make a self-assessment method through questionnaires according to different aspects. The customers make the same queries. After ranking from both sides, the results will be compared and confronted with the supplier. The effects on different areas and the nexus with supplier in the aftercare period will be examined in this study. The relation between the communication and reaction modes at the procurement side is deeply discussed.
\end{abstract}

Keywords: Procurement, Supplier evaluation, Performance, Self - assessment, Logistics

\section{Introduction}

The new generation will grow in a world that is characterized by almost real-time information flow and fast flow of people, goods and services. The 'digital native' generation will not feel the differences between real and virtual collapse and will navigate much more differently and more accurately between spheres that are more and more closely aligned with each other than previous generations. Individual products, events, nations, phenomena and individuals are becoming more and more closely related, dependent on each other, and interacting more than ever.

As a result, almost all processes take place much faster. The smallest time loss can also be the choice between success and failure. Nowadays the importance of

\footnotetext{
${ }^{*}$ Corresponding Author
} 
information is speeding. With the help of the Internet, the acquisition of this information is not a question, only the achievement and speed of that information is a great advantage for companies. As long as companies have delivered their orders to suppliers by letter, fax or e-mail, today, through the online Electronic Data Interchange (EDI), supply-on or other management system, the supplier can see in real-time the demand for that customer order component therefore the supplier can react immediately [1].

With the development of new technologies, the globalized, interconnected world allows us what we have done so much more efficiently and sustainability. [2]

\section{The challenge and the solution}

\subsection{Complexity and flexibility}

In the aircraft industry the components' complexity is visible. One aircraft depending on a model and type may consist of 500,000 - 5 Mio parts. Boeing 787 Dreamliner is assembled by about 1,000 workers in a factory in Everett, Washington [3].

The wings are made in Japan, the horizontal planes in the Italian Foggia, a part of the doors in Sweden, the wing holes in Korea, the cockpit seats in United Kingdom, and a part of the interior is made in Nyírbátor, Hungary [4]. The detailed location of the parts is shown in Fig. 1.

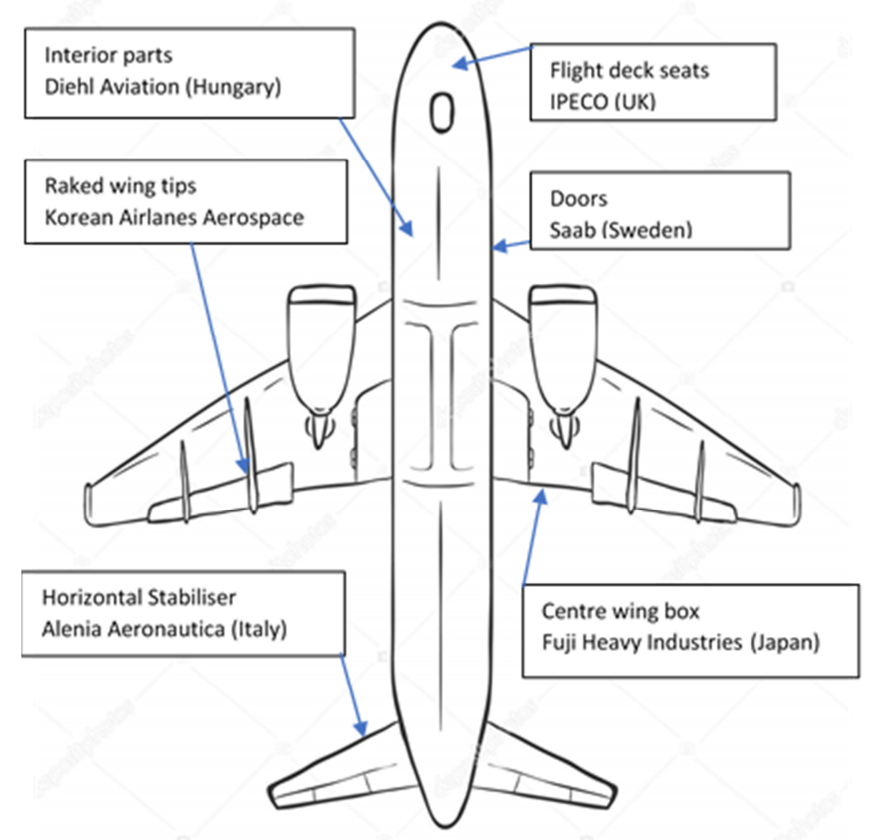

Fig. 1. Suppliers of Boeing 787 Dreamliner (Source: Author)

Pollack Periodica 14, 2019, 3 
Like most products that are bought and used, Dreamliner is also a product of a huge resource network. However, the increasing interdependence of the physical production of products is nothing compared to the leap that having been witnessed over recent years in digital connectivity.

Boeing's efficiency is increased by the outsourcing of sub processes, but processes affecting several dozen countries in several continents are fragile. A successful assembly of an aircraft or other complex machines depends not only on the integrity of some factories and suppliers, but also on the safety of ocean routes, working conditions, natural catastrophes, the stability of exchange rates and the flexibility of supply chain management.

With crowdsourcing and virtuality the network of available suppliers will be wider.

\subsection{Solution}

The industrial companies are generally mistaken in focusing on their own internal processes, developing them. This improvement is harmonized with the customer requirement and only in the middle and end of the supply chain is concentrated. Few companies cross functional overview and supplier-oriented purchasing [5], there is not enough emphasis on the beginning of the supply chain. In fact, the first and most important step begins with suppliers. If they are not prepared for just in time delivery or other scheduled deliveries, then the internal process improvement does not make sense. The high quality of the product must keep from the raw or purchased material. If from the external source the semi-finished parts or a material is delivered with small defect or it is not in required condition, then those mistakes will be built in the finished product. The operations must be tuned together between the manufacturer and the strategic supplier.

Traditional supplier performance measures may limit the possibilities to optimize supply chains as the management does not 'see' wide areas for improvement. This note raises issues critical to measuring this performance. A new measurement approach should lead the way to supply chain competitiveness and should direct management attention to areas for future optimization [6].

This communication is possible in several ways. The widespread and most commonly used one is a yearly or regular supplier evaluation letter, but this is only almost one-way communication. For suppliers it is very important to have not only a feedback but also a support or continuous guidelines [7].

Measuring the suppliers' performance helps companies to focus on resources on value added activities instead of reacting to supplier-induced problems (defects, late deliveries to customer, work stoppages, reduction of market competitiveness etc.) [8].

In annual evaluation several parameters can be measured:

- Number of complaints;

- Other quality parameters;

- Delivery performance;

- Quantity performance;

- Packaging performance;

- Other logistics parameters. 
One example is presented in Table $I$ for annual supplier performance measurement system where is analyzed the main viewpoints.

Table I

Suppliers' evaluation (Source: Author)

\begin{tabular}{|c|c|c|c|c|c|c|c|c|}
\hline \multicolumn{2}{|c|}{$\begin{array}{c}\text { Recieved } \\
\text { goods }\end{array}$} & \multirow{2}{*}{$\begin{array}{c}\text { Number } \\
\text { of } \\
\text { complai } \\
\text { Pts }\end{array}$} & $\begin{array}{c}\text { Quality } \\
\text { evaluati } \\
\text { on }\end{array}$ & & $\begin{array}{c}\text { Delivery } \\
\text { performa } \\
\text { nce }\end{array}$ & $\begin{array}{c}\text { Quantity } \\
\text { performa } \\
\text { nce }\end{array}$ & $\begin{array}{c}\text { Logistic } \\
\text { s } \\
\text { evaluati } \\
\text { on }\end{array}$ & \multicolumn{2}{|c|}{$\begin{array}{l}\text { Overall } \\
\text { supplier } \\
\text { evaluation }\end{array}$} \\
\hline 26 & $\begin{array}{r}215 \\
856\end{array}$ & 0 & 100 & 80 & 76 & 78 & $\begin{array}{c}92.3 \\
0\end{array}$ & A \\
\hline \multicolumn{2}{|c|}{ Previous ranking: } & A & & & & & & \\
\hline
\end{tabular}

According to the classification the supplier can reach following points:

- $\quad \boldsymbol{A}$ - Supplier (100 to 90):

Best suppliers, with a best performance no further feedback is required.

- $\quad$ AB - Supplier $(<90$ to 80$)$

Good suppliers, only internal measures are needed that need not be communicated to the customer

- $\quad B$ - $(<80$ to 60$)$ or $C$ - Supplier: $(<60)$

In a short time frame, a written action plan is needed to identify the tools and plan to improve the processes.

- $\quad$ - Supplier: $(<60)$

Suppliers with bad metrics it is needed to find an alternative supplier and need to be replaced in a short time.

After this information is not or only in case when the supplier achieves bad ranking then is expected any feedback or action plan. This is almost one-way communication, with only a low level of feedback [9].

\section{Supplier performance measurement system}

Supplier Performance Measurement (SPM) system is a new level of the cooperation with strategic-partners because the supplier receive continuous feedback and defined way of improvement. This is a new evolution of performance measurement system, which can be extended in a whole supply chain [10].

\subsection{System structure}

The structure of SPM system concentrated not only in one area, many functional parts and almost all important processes are analyzed and checked. The following Departments are under the scope in the SPM system: 
- Quality;

- Logistics;

- Cost structure;

○ Quotation process;

○ Savings/cost compliance;

- Improvement;

○ Competence of supplier;

- Technical equipment of supplier;

- Production;

- Customer Satisfaction;

- Customer orientation and flexibility of supplier;

- Contracts and other documents of supplier;

- Risk factors.

After the analyses the supplier can see a clear picture about their own processes.

\subsection{Specific question of logistics parts}

The logistics section represents one of the most important parts of interorganizational discussion [11].

Question of logistics;

1. Logistics quality: Was the supplier the cause of special trips to company or customers due to logistics errors, quality defects, production failure?

Evaluation:

10 point $=$ if no special trips needed;

1-9 point $=$ special trips without a production time stops;

0 point $=$ special rides with stoppage.

2. Capacity management: How does the supplier (including its subcontractors) comply with promised production capacity? How flexible is their response to fluctuations in demand, especially demand peaks?

For example:

Capacity check;

Flexible working hours;

Special shifts.

Evaluation:

10 point $=$ requirements fully met;

8 point $=$ predominantly fulfilled; minor deviations;

6 point $=$ partially fulfilled; major deviations;

4 point $=$ insufficiently fulfilled; serious deviations;

0 point $=$ not satisfied.

3. Electronic communication: Does the supplier use electronic procedures like dial-up connection, WEB-EDI, Vendor Managed Inventory (VMI) or are they willing to do so at the request of the buyer company?

Evaluation:

10 point $=$ active use of WEB-EDI, or other electronic communication system; 
6 point $=$ other dial-up connection active;

4 point $=$ readiness available;

0 point $=$ no connection active.

4. Warehousing: Is the supplier prepared to set up a consignment warehouse or Kanban at the request?

Evaluation:

10 point $=$ experience with other customers, already in use;

6 point $=$ experience with other customers, willingness available;

4 point $=$ no experience, but willingness available;

0 point $=$ no readiness.

5. Packaging development: Does the supplier independently suggest solutions for packaging of the products?

Evaluation:

10 point $=$ high initiative, very good proposals;

4 point $=$ no initiative, only under customer pressure;

0 point $=$ no initiative, no own suggestions.

6. Packaging and product labeling: Is the labeling of products and the labeling of packaging in accordance with the buyers specifications and requirements?

For example:

details of type, part number, batch, etc;

Barcode label;

Evaluation: Radio Frequency IDentification TAG (RFID TAG).

10 point $=$ requirements fully met;

8 point $=$ predominantly fulfilled; minor deviations;

6 point $=$ partially fulfilled; major deviations;

4 point $=$ insufficiently fulfilled; serious deviations;

0 point $=$ not satisfied.

\subsection{Operation}

Using this system the supplier will have the possibility to make a self-assesment method through questionnaires according to different aspects. (Quality, Logistics, Cost Structure, Improvement, Production, Customer Satisfaction, and Risk factors). The customers make the same queries.

It is important to make this evaluation separately, and as there is not too much time between evaluating the two sides because it can distort the values. After ranking from both sides the results will be compared and confronted with the supplier. This deeply common analysis of results and deviation is needed in a framework of a personal consultation. In mail communication it is not effective to clear the results, why the supplier got so many points on that question line. After the evaluation from both sides the differences in each area can be seen quickly and clearly as it can be seen in Table IITable IV, or as it is shown in a grid diagram of common areas in Fig. 2. 


\subsection{Results}

It is easy to determine how suppliers perceive the communication process and its impact on suppliers' performance. Specifically, the supplier evaluation communication process does not ensure improved supplier performance unless the supplier is committed to the buying firm. Buying companies can influence the supplier's commitment through increased efforts of cooperation. The results also indicate that when a buying firm utilizes collaborative communication, it is a positive influence on the buyer-supplier relationship [12].

In the example it is obvious that the external risk and contracts/documents is completely identical, the production and technical equipment side is a similar, but there is great difference in logistics, customer orientation, quotation, quality, cost savings, insurance and competence of suppliers' side. With this SPM suppliers exact feedback for the next period can be received, namely in which way their own development must be focused on.

Table II

Suppliers performance analysis details (Source: Author)

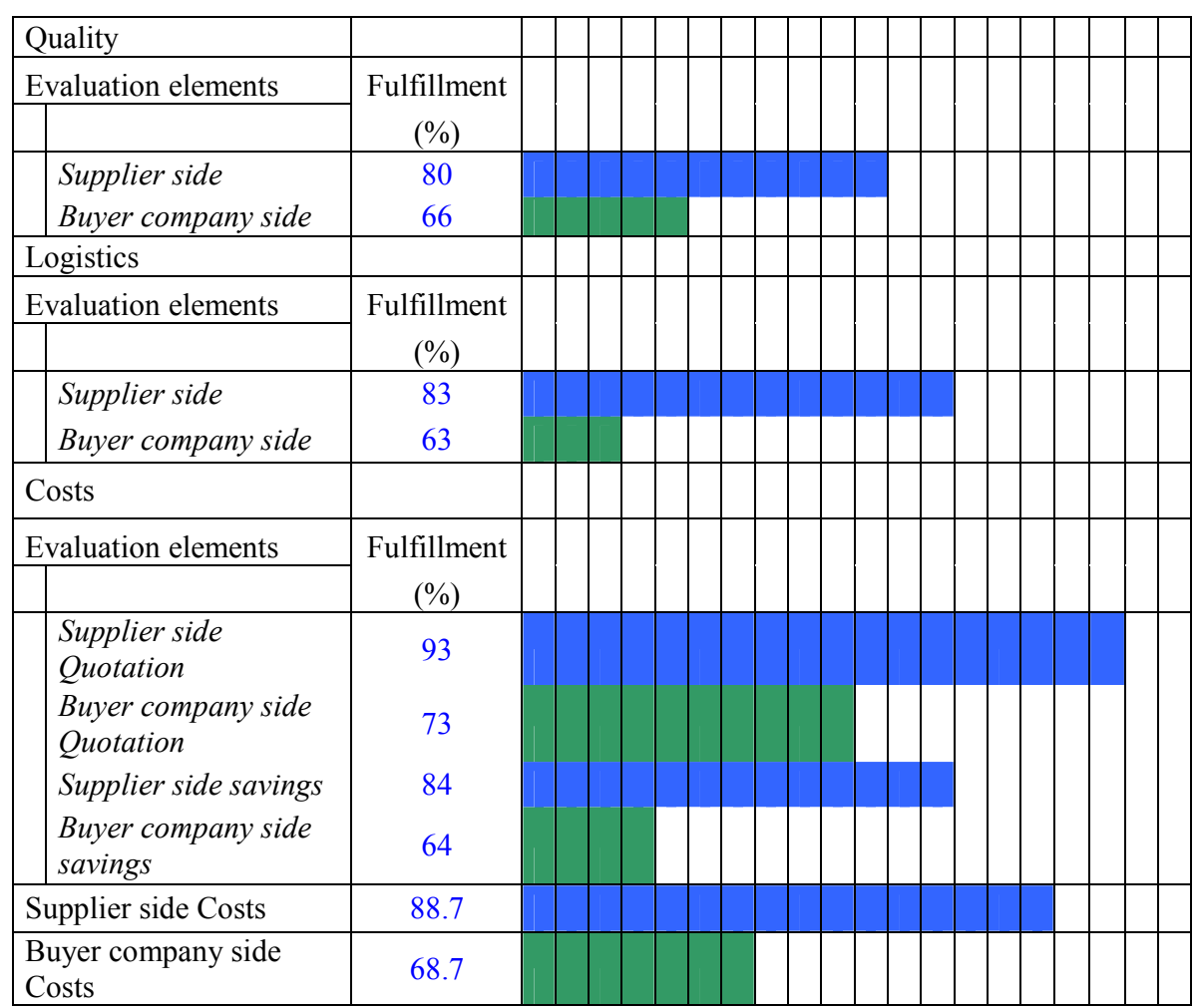


Table III

Suppliers performance analysis details (Source: Author)

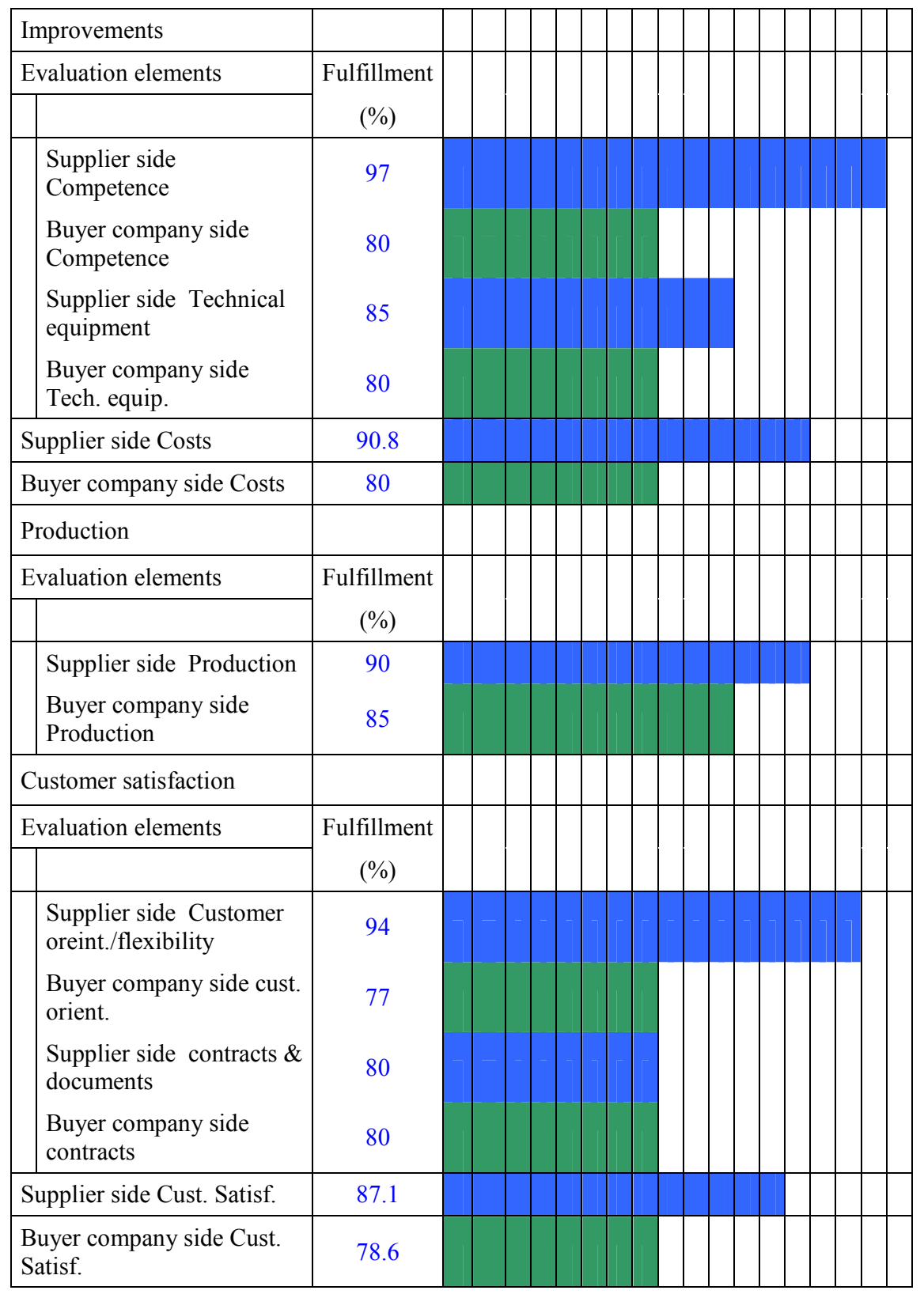

Pollack Periodica 14, 2019, 3 
The supplier can see a better picture from his own departments, processes and daily work, but on the other side the buyer company can show the way where improvement can be found and where it is needed.

This SPM measurement is essential to make every half a year or latest yearly, to check if the improvement is in the right direction or not. The continuous communication can help to develop an appropriate partnership in which the suppliers feel care and the possibility of a long-term cooperation.

Table IV

Suppliers performance analysis details (Source: Author)

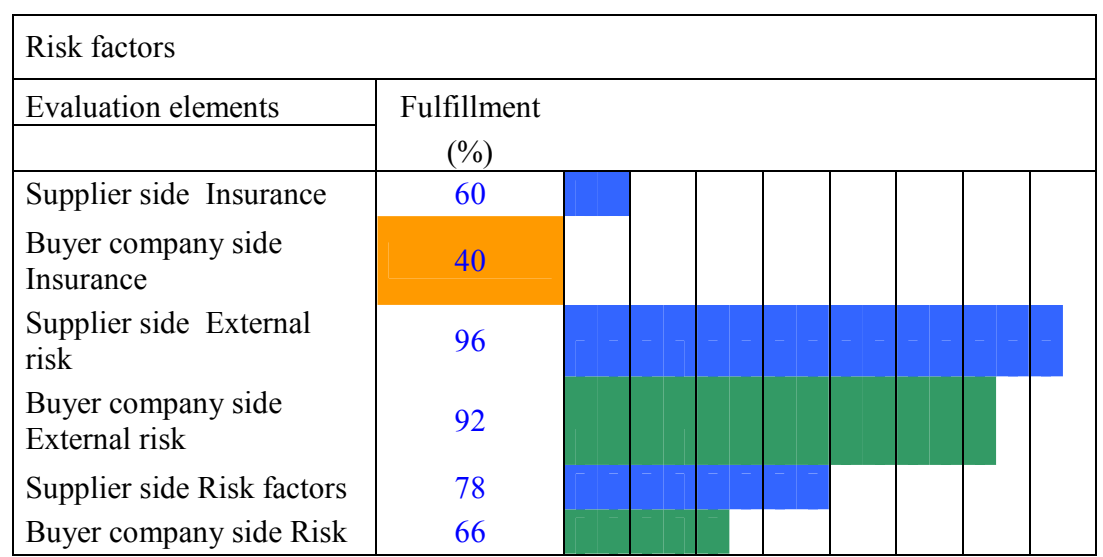

\begin{tabular}{|c|c|}
\hline Total result & $\begin{array}{c}\text { Fulfillment } \\
(\%)\end{array}$ \\
\hline Supplier side Total result & 85.4 \\
\hline Buyer company side Total & 72.5 \\
\hline
\end{tabular}

Half-year after the first SPM the second SPM results shows significant change The largest upswing was in terms of insurance, flexibility, competence of suppliers and quality. In case of production and technical equipment in the first measurement there was a difference and half a year later by the second round there was the same score on both sides.

From the results it is clear that the system can fill the actual communication gap between the customer and the supplier.

As suppliers take on more important roles in manufacturing and designing products, their operational innovativeness becomes an important source of value [13].

In the past, commonly used supplier evaluative criteria have focused on quality, service or delivery, and price. In recent years, the channels literature has indicated other areas, like relationship factors, external risk, insurance [14]. This method can be support the supplier selection problematic of the logistics. When one product ordered in a given quantity, but only one supplier cannot provide all of the ordered quantity because of lack of capacity, and more suppliers have to involve is described [15]. Implementation 
and adaptation in the other direction of logistics for example on the transport companies, in a long-term target are the optimal input/output structure [16].

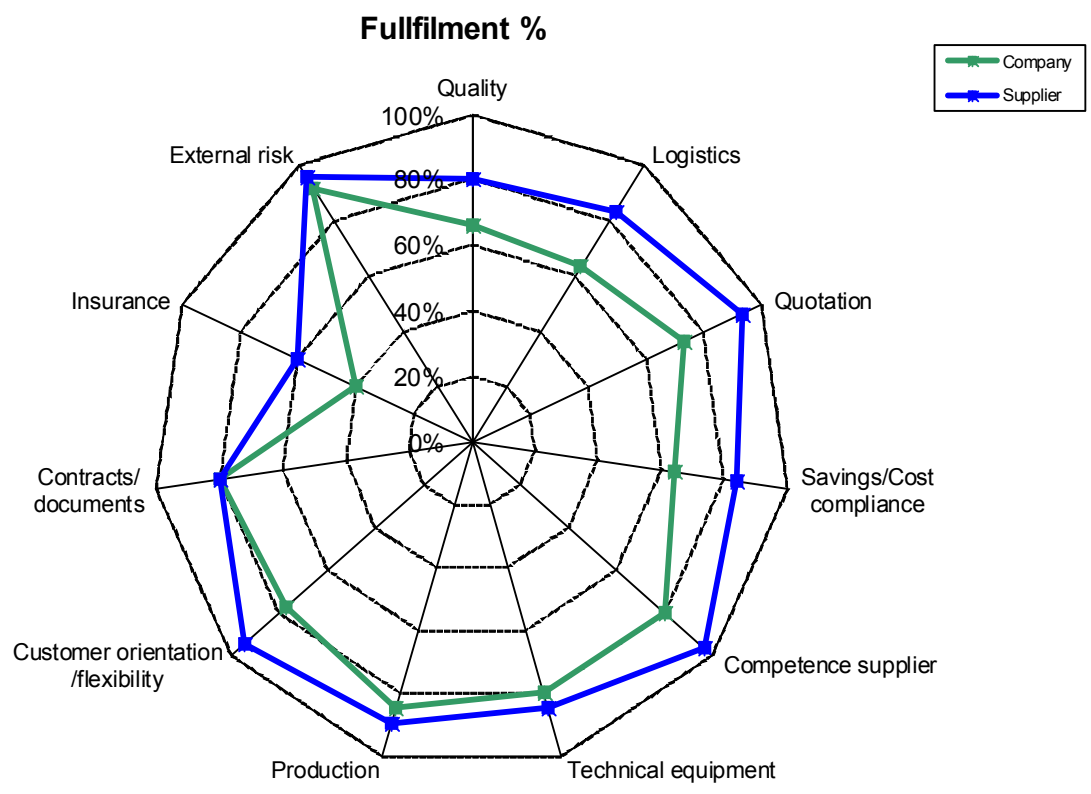

Fig. 2. Suppliers performance comparison (Source: Author)

\section{Conclusion and future steps}

The development of the SPM system was preceded by a longer research and fieldby-field consultation, when the final version was developed, with which a comprehensive, cross-departmental study could be conducted. The results clearly show the future direction of development.

In all industrial, non-industrial, service sectors there is a need for supplier evaluation, but it is necessary to set up a company or area specific evaluation criteria and system separately.

This supplier performance system has been started in the industrial sector. It is only filled for strategic suppliers. It makes no sense for those suppliers with whom the company is not planning in the long term, as it is very time consuming to prepare.

Next steps:

- In a short term-period more data and result is needed to have a clear picture how the SPM system can be optimized;

- In a middle term-period it will be useful to make a different second round questioners to have a higher level of cooperation with strategic partners; 
- In a longer term-period it is possible to make an industrial sector specific SPM system (for example: Food industry in focus on hygiene, in service sector focused on a customer satisfaction, in pharmaceutical industry focused on a healthy and safety work with a traceability).

\section{Open Access statement}

This is an open-access article distributed under the terms of the Creative Commons Attribution 4.0 International License (https://creativecommons.org/licenses/by/4.0/), which permits unrestricted use, distribution, and reproduction in any medium, provided the original author and source are credited, a link to the $\mathrm{CC}$ License is provided, and changes - if any - are indicated. (SID_1)

\section{References}

[1] McChrystal G. S., Collins T., Silverman D., Fussell C. Team of teams: New rules of engagement for a complex world, Penguin, 2015.

[2] Kannan D. Role of multiple stakeholders and the critical success factor theory for the sustainable supplier selection process, International Journal of Production Economics, Vol. 195, 2018, pp. 391-418.

[3] Dominic G. Boeing 787 Parts from around World will be swiftly integrated, Seattle Times, 11 September 2005.

[4] Boeing 787 Dreamliner global supplier https://avpasc.com/supportedaircrafts/boeing?gclid=EAIaIQobChMIvICHrKC23wIVleJ3Ch3XBgdJEAAYASAAEgWa PD_BwE (last visited 12 of September 2018).

[5] Jääskeläinen A. Comparison of performance measurement in different purchasing and supply management practices, International Journal of Productivity and Performance Management, Vol. 67, No. 8, 2018, pp. 1290-1309.

[6] van Hoek R. I. Measuring the unmeasurable - measuring and improving performance in the supply chain, Supply Chain Management: An International Journal, Vol. 3, No. 4, 1998, pp. 187-192.

[7] Shaw S., Grant D. B., Mangan J. Developing environmental supply chain performance measures, Benchmarking: An International Journal, Vol. 17, No. 3, 2010, pp. 320-339.

[8] Gordon S. R. Supplier evaluation and performance excellence: A guide to meaningful metrics and successful results, J. Ross publishing, 2008.

[9] Prahinski C., Fan Y. Supplier evaluations: The role of communication quality, Journal of Supply Chain Management, Vol. 43, No. 3, 2007, pp. 16-28.

[10] Hald K. S., Mouritsen J. The evolution of performance measurement systems in a supply chain: A longitudinal case study on the role of interorganizational factors, International Journal of Production Economics, Vol. 205, 2018, pp. 256-271.

[11] J. Schmitz, K.W.Platts: Supplier logistics performance measurement: Indications from a study in the automotive industry, International Journal of Production Economics, Vol. 89, No. 2, 2004, pp. 231-243.

[12] Prahinski C., Benton W. C. Supplier evaluations: communication strategies to improve supplier performance, Journal of Operations Management, Vol. 22, No. 1 2004, pp. 39-62.

[13] Azadegan A. Benefiting from supplier operational innovativeness: The influence of supplier evaluation and absorptive capacity, Journal of Supply Chain Management, Vol. 47, No. 2, 2011, pp. 49-64. 
[14] Simpson P. M., Siguaw J. A., White S. C. Measuring the performance of suppliers: An analysis of evaluation processes, Journal of Supply Chain Management, Vol. 38, No. 4, 2002, pp. 29-41.

[15] Kota L., Jármai K. Efficient algorithms for optimization of objects and systems, Pollack Periodica, Vol. 9, No. 1, 2014, pp. 121-132.

[16] Markovits-Somogyi R., Bokor Z. The effect of data structure on the DEA-based efficiency ranking in logistics, Pollack Periodica, Vol. 7, No. 1, 2012, pp. 123-134. 